\title{
On the occurrence of a lessepsian immigrant Scomberomorus commerson (Scombridae) in Izmir Bay (Aegean Sea, Turkey)
}

\section{Bir lesepsiyen göçmen Scomberomorus commerson'un (Scombridae) İzmir Körfezi'nde (Ege Denizi, Türkiye) bulunuşu üzerine}

\author{
Okan Akyol ${ }^{1 *} \bullet$ Zafer Tosunoğlu² \\ 'Ege University Faculty of Fisheries, 35440 Urla, Izmir, Turkey (iD https://orcid.org/0000-0001-7738-2156 \\ Ege University Faculty of Fisheries, 35440 Urla, Izmir, Turkey (iD https://orcid.org/0000-0002-1168-9611 \\ *Corresponding author: okan.akyol@ege.edu.tr
}

Received date: 31.10 .2018

Accepted date: 16.01 .2018

\section{How to cite this paper:}

Akyol, O. \& Tosunoğlu, Z. (2019). On the occurrence of a lessepsian immigrant Scomberomorus commerson

(Scombridae) in Izmir Bay (Aegean Sea, Turkey). Ege Journal of Fisheries and Aquatic Sciences, 36(1), 81-84.

DOI: 10.12714/egejfas.2019.36.1.10

\begin{abstract}
This paper reports the presence of Scomberomorus commerson in the Turkish Aegean Sea. A specimen, measuring $840 \mathrm{~mm}$ in TL, was captured off Gediz River Delta, Izmir Bay in the northern Aegean Sea on 06 October 2018. This short note contributes to the ichthyofaunal richness of the northern Aegean Sea, while presenting a new record of S. commerson in Izmir Bay.
\end{abstract}

Keywords: Lessepsian species, record, Izmir Bay, Aegean Sea

Öz: Bu makale Türk Ege Denizi'nde Scomberomorus commerson'un bulunuşunu rapor etmektedir. $840 \mathrm{~mm}$ total boyda ölçülmüş bir birey, 6 Ekim 2018 tarihinde Kuzey Ege Denizi'nde Gediz Deltası (İzmir Körfezi) açıklarından yakalanmıştır. Bu kısa not S. commerson'un İzmir Körfezi'nde yeni bir kaydını sunarken, kuzey Ege Denizi'nin de ihtiyofaunal zenginliğine katkıda bulunmaktadır.

Anahtar Kelimeler: Lesepsiyen tür, kayıt, İzmir Körfezi, Ege Denizi

\section{INTRODUCTION}

Narrow-barred Spanish mackerel, Scomberomorus commerson (Lacepéde, 1800) is a pelagic, highly migratory fish that usually hunts solitary and often swims in shallow water along coastal slopes. It feeds on mainly on schooling fishes such as anchovies, clupeids, carangids, also squids and shrimps. Maximum length is $240 \mathrm{~cm} \mathrm{FL}$, common length is $120 \mathrm{~cm} \mathrm{TL}$, and it reaches sexual maturity at $65 \mathrm{~cm}$ (Golani et al., 2006; Froese and Pauly, 2018).

S. commerson spreads originally throughout the Indo-Pacific from the Red Sea and South Africa to Australia and Fiji. It is immigrant to the eastern Mediterranean Sea via the Suez Canal where it can be found westward to at least Tunisia (Golani et al., 2006; Collette et al., 2011; Froese and Pauly, 2018).

In the Mediterranean, S. commerson firstly recorded in Palestine (Hornell, 1935), while has been known from Mersin and Iskenderun Bays, Turkey since 1981 (Gücü et al., 1994). Other successive records were shown in Table 1. This short note contributes to the ichthyofaunal richness of the northern Aegean Sea, while presenting a new record of S. commerson in Izmir Bay.

\section{MATERIAL AND METHODS}

On 06 October 2018, a specimen of Scomberomorus commerson, measuring $840 \mathrm{~mm}$ TL (Figure 1) was captured by a commercial purse-seiner targeting sardine off Gediz River Delta, Izmir Bay, northern Aegean Sea (coordinates: $38^{\circ} 33^{\prime} 41^{\prime \prime} \mathrm{N}-26^{\circ} 46^{\prime} 23^{\prime \prime} \mathrm{E}$ ) at a depth of $35 \mathrm{~m}$ (Figure 2). The specimen was fixed with $5 \%$ formaldehyde solution and deposited in the ichthyological collection of Ege University, Fisheries Faculty and received the following catalog number: ESFM-PIS/2018-08. 
Table 1. Records of Scomberomorus commerson in the Mediterranean Sea

\begin{tabular}{|c|c|c|c|c|c|c|}
\hline Location & $\begin{array}{l}\text { Coordinates } \\
\text { Lat. N-Lon. E }\end{array}$ & $\begin{array}{l}\text { Depth } \\
\text { (m) }\end{array}$ & Record Date & $\begin{array}{l}\text { Number } \\
\text { collected }\end{array}$ & $\begin{array}{l}\text { Size, TL } \\
(\mathrm{mm})\end{array}$ & References \\
\hline Coasts of Israel & $?$ & $?$ & 1971 & 3 & $360-460$ & Ben-Tuvia (1971) \\
\hline Coasts of Lebanon & $?$ & $?$ & $1970 \mathrm{~s}$ & 1 & $460^{\ddagger}$ & Ben-Tuvia (1978) \\
\hline $\begin{array}{l}\text { Mersin/Iskenderun } \\
\text { Bays }\end{array}$ & $?$ & $?$ & 1981 & 2 & $?$ & Gücü et al. (1994) \\
\hline Iskenderun Bay & $?$ & $?$ & 1991-1994 & 2 & $501-550$ & Torcu and Mater (2000) \\
\hline Güllük/Gökova Bays & $?$ & $?$ & Nov.-Dec.1994 & 70 & $520-870$ & Buhan et al. (1997) \\
\hline Iskenderun Bay & $?$ & $15-25$ & Dec.1994-Nov.1996 & 1 & 557 & Başusta and Erdem (2000) \\
\hline Alexandria, Egypt & $30^{\circ} 05^{\prime}-31^{\circ} 15^{\prime}$ & $?$ & Nov.1999-Jan.2001 & 178 & $40-600$ & Bakhoum (2007) \\
\hline Gökova Bay & $?$ & $?$ & $2000-2001$ & 1 & 1130 & Öğretmen et al. (2005) \\
\hline Yeşilova Bay & $?$ & $15-25$ & $2002-2004$ & $1^{+}$ & $?$ & Oz et al. (2007) \\
\hline off Kelibia, Tunisia & $36^{\circ} 52^{\prime}-11^{\circ} 10^{\prime}$ & 46 & 16 Oct.2004 & 1 & 312 & Ben Souissi et al. (2006) \\
\hline off Rhodes, Greece & $?$ & $12-14$ & 31 March 2008 & 1 & 1020 & $\begin{array}{l}\text { Corsini-Foka and Kalogir- } \\
\text { ou (2008) }\end{array}$ \\
\hline Benghazi, Libya & $?$ & $5-70$ & Aug.2010-Oct.2013 & 99 & $234-1400$ & Elbaraasi (2014) \\
\hline Izmir Bay & $38^{\circ} 33^{\prime}-26^{\circ} 46^{\prime}$ & 35 & 06 Oct. 2018 & 1 & 840 & This study \\
\hline
\end{tabular}

†underwater observation; ${ }^{\ddagger} \mathrm{SL}$

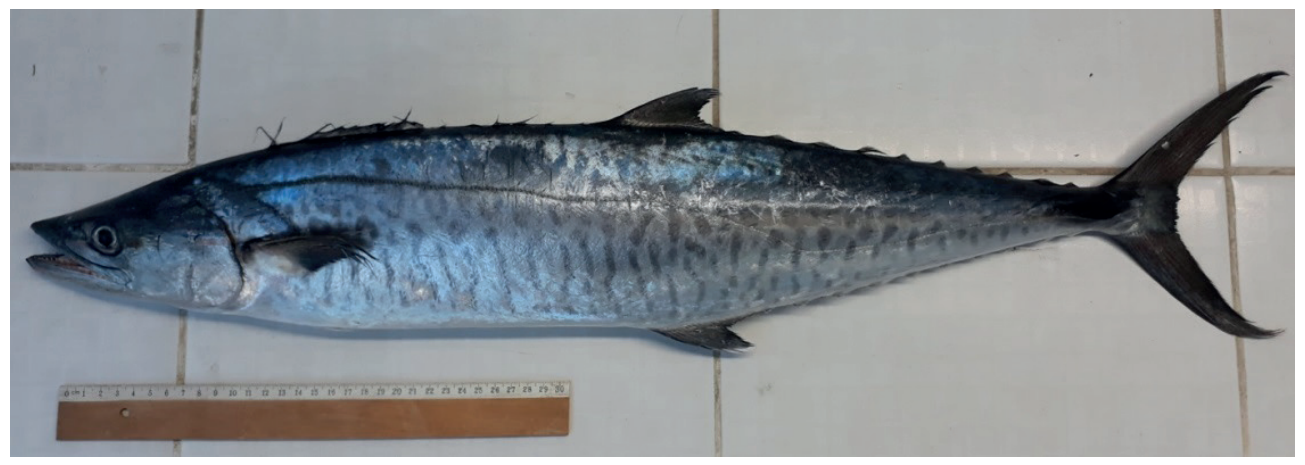

Figure 1. Narrow-barred Spanish mackerel, Scomberomorus commerson (ref. ESFM-PIS/2018-08), captured from Izmir Bay, NE Aegean Sea (photo: O. Akyol) 




Figure 2. Map of sampling area: black star indicates the capture site of Scomberomorus commerson in Izmir Bay, Aegean Sea

\section{RESULTS AND DISCUSSION}

Description, measurements and percent in total length (Table 2), recorded of the specimen are in total accordance with Buhan et al., (1997), Golani et al. (2006) and Froese and Pauly (2018).

Since the early 1970s, S. commerson has become established in the eastern Mediterranean Sea, including Israel and Lebanon records. Gücü et al. (1994) collected two specimens from Mersin coasts in 1981, and apparently, this was the first record for the Turkish seas. Then, the species reached to from Gökova and Güllük Bays (Turkey) in 1994 (Buhan et al., 1997) to Tunisia in 2004 and Rhodes Island in 2008 (Ben Souissi et al., 2006; Corsini-Foka and Kalogirou, 2008).

Though S. commerson is known by some fishermen and some divers from Izmir (I. Temiztepe and A. Özgül, pers. comm.), no specimen has been recorded up to now. The sampled fish was captured beneath an illuminated boat of purse-seiners, targeting sardine and anchovy. On the other hand, one of the places

\section{REFERENCES}

Bakhoum, S.A. (2007). Diet overlap of immigrant narrow-barred Spanish mackerel Scomberomorus commerson (Lac., 1802) and the largehead hairtail ribbonfish Trichiurus lepturus (L., 1758) in the Egyptian Mediterranean coast. Animal Biodiversity and Conservation, 30(2), 147-160.

Başusta, N. \& Erdem, Ü. (2000). A study on the pelagic and demersal
Table 2. Morphometric measurements in $\mathrm{mm}$ and as the percentage of total length (\%TL) and counts recorded in Scomberomorus commerson, captured from Izmir Bay, Aegean Sea

\begin{tabular}{lcc} 
Reference & \multicolumn{2}{c}{ ESFM-PIS/2018-08 } \\
Measurements & mm & \%TL \\
\hline Total length & 840 & 100.0 \\
Fork length & 732 & 87.1 \\
Standard length & 700 & 83.3 \\
Predorsal fin length & 160 & 19.0 \\
Prepectoral fin length & 155 & 18.5 \\
Pre-anal fin length & 385 & 45.8 \\
Head length & 148 & 17.6 \\
Eye diameter & 19 & 2.3 \\
Preorbitary length & 57 & 6.8 \\
Interorbital length & 49 & 5.8 \\
Counts & \multicolumn{2}{c}{ XVI+16+10 finlets } \\
Dorsal fin rays & $18+10$ finlets \\
Anal fin rays & \multicolumn{2}{c}{ I+5 } \\
Pectoral fin rays & \multicolumn{2}{c}{3153} \\
Ventral fin rays & \multicolumn{2}{c}{ Total body weight in gram } \\
\hline
\end{tabular}

where most shrimp is caught in Izmir Bay is the Gediz Delta region. Obviously, the fish has come to the boat, illuminated with strong light, for feeding on sardine, anchovy and shrimp. As a matter of fact the main diet preference of the S. commerson is anchovy, shrimps and sardine (Bakhoum, 2007). In conclusion, intermittently records show that $S$. commerson is still a rare species throughout the Mediterranean, even if it occasionally concentrates in large schools. On the other hand, this ichthyologic note presents the fish goes to northern latitudes step-by-step.

\section{ACKNOWLEDGEMENTS}

The authors thank captain and crew of purse-seiner "Afala", and TUBITAK project (no: 1180317).

fishes of Iskenderun Bay. Turkish Journal of Zoology, 24 (Suppl.), 1-19.

Ben Souissi, J., Golani, D., Mejri, H., Zaouali, J. \& Capapé, C. (2006). On the occurrence of Scomberomorus commerson Lacepéde, 1800 (Osteichthyes: Scombridae) off Northern Tunisia (Central Mediterranean). Cahiers de Biologie Marine, 47, 215-218.

Ben-Tuvia, A. (1971). Revised list of the Mediterranean fishes of Israel. 
Israel Journal of Zoology, 20, 1-39.

DOI: 10.1080/00212210.1971.10688323

Ben-Tuvia, A. (1978). Immigration of fishes through the Suez Canal. Fishery Bulletin, 76, 249-255.

Buhan, E., Yılmaz, H., Morkan, Y., Büke, E. \& Yüksek, A. (1997). A new potential catch for Güllük Bay and Gökova Bay: Scomberomorus commerson (Lacepéde, 1800) (Pisces:Teleostei). Akdeniz Balıkçılık Kongresi, Bildiri Kitabı, 9-11 Nisan, Izmir, pp. 937-944. (in Turkish).

Corsini-Foka, M. \& Kalogirou, S. (2008). On the finding of the IndoPacific fish Scomberomorus commerson in Rhodes (Greece). Mediterranean Marine Science, 9(1), 167-172.

DOI:10.12681/mms.147

Collette, B., Chang, S.-K., Di Natale, A., Fox, W., Juan Jorda, M., Miyabe, N., \& Nelson, R. (2011). Scomberomorus commerson. The IUCN Red List of Threatened Species 2011: e.T170316A6745396. DOI: 0.2305/IUCN.UK.2011-2.RLTS.T170316A6745396.en

Elbaraasi, H. (2014). Length-weight relationships for five Lessepsian fish species from the coast of Benghazi, Libya (Southern Mediterranean). Agriculture, Forestry and Fisheries, 3(3), 178-180. DOI: 10.11648/j.aff.20140303.16
Froese, R. \& Pauly, D. (2018). FishBase. World Wide Web electronic publication. Retrieved from http://www.fishbase.org

Golani, D., Öztürk, B. \& Başusta, N. (2006). The Fishes of the Eastern Mediterranean. Turkish Marine Research Foundation, Publication No. 24. Istanbul, 259 pp.

Gücü, A.C., Bingel, F., Avsar, D., \& Uysal, N. (1994). Distribution and occurrence of Red Sea fish on the Turkish Mediterranean coastnorthern Cilician basin. Acta Adriatica, 34(1/2), 103-113.

Hornell, J. (1935). Report on the Fisheries of Palestine. Government of Palestine. Crown Agent for the Colonies, London. 106 pp.

Öğretmen, F., Yılmaz F. \& Torcu Koç, H. (2005). An investigation on fishes of Gökova Bay (Southern Aegean Sea). BAÜ Fen Biimleri. Enstitüsü Dergisi, 7(2), 19-36.

Öz, I., Okuş, E. \& Yüksek, A. (2007). Notes on the erythrean alien fishes of Datça-Bozburun Peninsula - a specially protected area in the south eastern Aegean Sea (Turkey). Rapp. Comm. int. Mer Médit., 38, pp. 563.

Torcu, H. \& Mater, S. (2000). Lessepsian fishes spreading along the coasts of the Mediterranean and the southern Aegean Sea of Turkey. Turkish Journal of Zoology, 24, 139-148. 